\title{
Marginalised in the New Wave Tamil Film: Subaltern Aspirations in three films by Bala, Kumararaja and Mysskin
}

\author{
Sreeram Gopalkrishnan \\ Symbiosis International University, sreeram.gopalkrishnan@scmc.edu.in, \\ Orcid id https://orcid.org/oooo-ooo1-936o-365X. Scopus id 56659374000
}

\begin{abstract}
In the last decade a new kind of Tamil film was noticed, widely celebrated as new wave, neo-noir, 'Madurai genre' and even as a backlash to the 'Rasigar Mandram'(Fan Clubs) Stars of mainstream cinema. The rise of such films was in itself an achievement considering the commercial stranglehold of the politico-cultural ecosystem in the Tamil film industry. The new directors moved away from the bubble of 'mass scene'(grand super hero entry scene) appearances, political innuendos, super star 'punch' dialogues and fan club worship of pouring milk on opening day giant-size 'cutouts'. What the new Tamil films did portray were marginalized, subaltern low-caste characters with aspirations built around grim storylines, expository dialogues and dark themes. This article endeavors to thematically analyse three 'new wave' Tamil films and trace the underlying strains of a new generation narrative drawn out from the dirty underbelly of 'postDravidian Rajni-persona Superstar cinema'.
\end{abstract}

Keywords: Tamil New Wave, Neo Noir, Marginalised, Film, Caste, Rajini-persona

\section{The post Rajini-Persona Tamil Film}

In the large and diverse Indian film world the Tamil Film industry is distinct due to its unique 'Politico-Cultural' dimension with facets of linguistic exceptionalism and rationalistic philosophy packaged into the Dravidian ideological movement (M.S.Pandian, 1995). The film industry in the Dravidian/political firmament interrogated the dominant northern based nationalistic, nation building, Hindi-dominant and state-capitalist imperatives that informed the postcolonial 'Nehruistic' philosophy of nation building. The 'temples of modern India' did not resonate to those who were repugnant to the temple of blind belief and religious tyranny of orthodoxy. From projecting a glorified Dravidian cultural heritage the movement to mobilizing Tamil ethnonationalism it made language the foundation of a Tamil nation ${ }^{\mathrm{i}}$. Ironically, despite such a formidable Dravidian ecosystem covertly built under the foundations of a new nation state, one non-Tamil, a former bus conductor, Rajinikanth rose to become a mass based super star hero, portraying a menacing and macho anti-hero who excelled in glamorizing and humanizing lumpen proletariat roles.

Rising as an alter ego to the MGR-Karunanidhi template of Dravidian popular cinema the 'Rajini-persona' closely adhered to the definitions of appropriate Tamil masculinity, embodied a subaltern persona ${ }^{\text {ii }}$ that became a symbol of rebellion (Maderya, 2010). With a subversive charisma that resonated with the subaltern - economically disenfranchised, lower classes and marginalized castes with colorism tones ${ }^{\text {iii }}$ the Rajini-persona was no longer 'fair skinned' as the

(c) AesthetixMS 2019. This Open Access article is published under a Creative Commons Attribution Non-Commercial 4.0 International License (http://creativecommons.org/licenses/by-nc/4.o/), which permits non-commercial re-use, distribution, and reproduction in any medium, provided the original work is properly cited. For citation use the DOI. For commercial re-use, please contact editor@rupkatha.com. 
MGR-Sivaji-Gemini Ganesan stereotype. Soon the raw Rajini-persona identification was submerged in the mainstream box office compulsions with Rasikar Manrams(fan clubs) and a deluge of Rajni-fied actors sprouted across the state, fed increasingly by fanatical fans, heroworship and the dominant nexus of the star-producer-distributor even creating a suspect ${ }^{\text {iv }}$ 'Rasigar Manram' customer loyalty program.

With the 1990s and liberalisation, an increasingly urbanised state saw the emergence of Maniratnam whose films were aesthetically modern and stylistic with cosmopolitan Brahmincoded characters that were fair skinned, middle-class and had contemporary liberalist problems (Niranjana, 1994). What then followed was wholesome entertainment with white skinned North Indian heroines romancing older, swarthy dark skinned heroes (Rajnikanth's character even attempted a white bleach version in Sivaji The Boss, $2007^{\mathrm{v}}$ ). But change was coming in the form of a globalised Tamil diaspora exposed to foreign television and international film cultures. The mass scene-action genre, which regularly paid homage to the superstar, personality cults, sentimentality and paternalism were seen as anachronistic. Ominously, from 2004, there was a steady failure of 'mass hero' mega budget films(Rajan Krishnan, 2010) in the face of rampant unequal growth, disillusionment of Dravidian style dynast politics due to family fiefdoms of the founding leaders, rapidly urbanizing ghettos, the political weaponising of the marginalised castes through social media; all a volatile combination waiting to explode.

The typical Tamilnadu small town is endowed with a paradoxical blend of modern amenities and caste-driven identity, with a large number of underprivileged who cope with poverty in a representation of the subaltern urbanism (Marie-Helene Zerah, 2017). In India, the marginalized is also 'subaltern'(Marcus E Green 2011), comparable to the BPL majority in juxtaposition to the miniscule minority at the top of the pyramid(Ranajit Guha, 1982) laying the ground for the marginalized subaltern to speak, be heard, perform resistance, challenge power structures, and gain social mobility (Gayatri Spivak, 2010). Giving voice to them was a new set of film-makers who went back to their roots to tap the lower end of the societal power continuum. In their films, the marginalized rises above his dirty clothes, sweaty visage, dark skin and revels in the individuality of his violence and rustic language contrasted to the 'make-up' enhanced establishment 'mass' hero.

\section{The voice of the marginalized}

In 1999 end, a Tamil film Sethu ${ }^{\text {vii }}$ started making news. Released in a single theatre in Chennai metropolis(the largest city in Tamilnadu State, South India), it soon began running to packed houses, marketed purely through word of mouth. The film was novel but there have been such novelty before, especially in the 1970s, when Mahendran, Balu Mahendra and Bharathiraja began making movies ushering in the era of a mini-parallel cinema ${ }^{\text {viii }}$. But this time it was different and Sethu was followed by other films with raw and shocking themes from below the radar of popular mainstream cinema. Like the Chennai marginalised (Pudhupettai, 2006), caste evilness in the rural village (Paruthiveeran, 2007), bone-chilling honour killings (Kadhal, 2004) followed by Katrathu Tamizh (What I Learnt was Tamil), Veyil (Sunshine), Chennai 6ooo28, Polladhavan (A Vile Man), Anjathey (Don't Fear), Subramaniapuram, Poo (Flower), Vennila Kabadi Kuzhu (The White Moon Kabbadi Team) and Naan Kadavul (I Am God). Later films like Naduvula Koncham Pakkatha Kanom (Some Pages are Missing in between), Pizza, Soodhu Kavvum (Vice Engulfs), Visaranai (Investigation), Jigarthanda and Kakka Muttai (A Crow's Egg) cemented the reputation of a new wave of Tamil films. 
The eminent film historian, K.Hariharan called these new Tamil films the "cinema of disgust $^{\text {pix }}$ for its exploration of the grotesque and human. The gritty film template with shocking themes was creeping in slowly but not without consequences ${ }^{\mathrm{x}}$ of a blowback from the mainstream establishment. The flagship action-masala industry did not take kindly to this development and the new wave, independent film makers were soon facing market realities of distribution and expensive promotion. But the 'films of disgust' continued dismantling the 'mega mass hero', braving the political-cultural ecosystem with characters that were anti-villains, flexi-villains, dysfunctional, mercenaries, schizophrenics, non-heroic rustic nobodies who couldn't pass the lowest end of a charitable 'charismatic' screen test. In fact, they were represented as almost dangerous, anti-social and deviant like Murugan (Kadhal), Murugesan (Veyil), Veera and Sevvazhai (Paruthiveeran), Azhagar and Parama (Subramaniapuram) with such stark reality that the celebrated Bollywood Director Anurag Kashyap even acknowledged them as influences in his philosophy ${ }^{\mathrm{xi}}$, paying homage to them in his films ${ }^{\mathrm{xii}}$.

Tamil films were also influenced externally before as Kumuthan Maderya ${ }^{x i i}$ argues with narratives of Tamil cinema's 'revolutionary art films' of the 1980s symptomatic of the social conflicts and ideological civil wars of the cold war. But there was a difference in the new wave in that it was the rise of the lower castes to the mainstream. Despite Tamil actor-politicians and mass heroes moving quickly to safeguard any challenge to the film-political ecosystem of the state, the simmering tensions of the subaltern castes found an outlet. Caste is a multidimensional crime and has survived in Tamilnadu despite decades of Dravidian anti-caste rationalist propaganda. The rise of the Madurai genre was actually a precursor to the new wave and Dickens Leonard $^{\mathrm{xiv}}$ using the concept of heterotopias analysed Madurai as a cultural motif for films, especially in the depiction of caste. Using the genre(Madurai is the third largest city in Tamil $\mathrm{Nadu}$ ), he examined popular films, bearing caste names and content, constructing a cinematic imaginary of southern Tamil Nadu as 'a distinct entity submerged in pre-modern violence, caste bigotry and anarchy’ (Krishnan, 2008).

\section{Film Noir or Not}

The Tamil new wave films were also referred to as neo-noir with 'shifts within the code of hegemonic Tamil masculinity' as well as the 'self-reflexivity and dark humour' to narrate in the post-Dravidian moment (V.Kailasam, 2017). The noir genre in Tamil does have some history with Andha Naal (That Day), widely regarded as the first film with noir influence ${ }^{\mathrm{xv}}$ set in Chennai (then Madras) during the bombing by Japanese forces in 1943(S.E. Pillai, 2015) and extensively used noir lighting with the main protagonist played by a leading actor (Sivaji Ganesan) portrayed as an antihero with a virtuous wife (Yves Thoraval) ${ }^{\mathrm{xvi}}$. But the word 'Film Noir', first coined by French film critics (Nino Frank, 1946) referred to a type of dark American films which emerged from the experimentation in German expressionism (Fritz Lan's M 1931), pulp fiction books and realism marked by the rise of the urban setting of the City as a character with writers like Dashiell Hammett, a poster boy ${ }^{\text {xvii }}$ for the genre ${ }^{\text {xviii }}$.

More than a genre, noir is considered a style of cinematography that is largely night-time, high-contrast low-key lighting, shadows and oblique angles. It also had a stylized narrative often using a voice-over exploring the psychology of the male protagonist amidst the presence of a femme fatale in the background of pessimism and depression. The setting was usually an urban contemporary world - a city at night - with fallible or tarnished characters. Many film scholars argue that Film Noir was reconstructed as a genre only in retrospect ${ }^{\text {xix }}-$ i.e. at the time of 
production they may not be aware that a film noir was, in fact, what they were producing (Neale 2000).

In that context, Indian Noir films cannot typically be taken as 'noir' though some Hindi films ${ }^{\mathrm{xx}}$ almost all set in (then) contemporary Bombay ${ }^{\mathrm{xxi}}$, regularly featured characteristic elements of Hollywood film noir, including heroes who skirt the border of legal and illegal activity. Like their counterparts in American film noir, these were streetwise men who negotiated the new swanky nightclubs featuring alluring femme fatales (often westernized by clothing, smoking and drinking). Accepting some influence these films were unlike American film noirs - the hero was no cynic and there were no quick sardonic dialogue to off-set the dreary mood. Most had songs ${ }^{\text {xii }}$, to add a Bollywood Trollope, and some even had the femme fatale singing tragically and elusively (Mahal, 1949) in a large mansion and claimed a connection from an earlier life (Madhumati 1958)

\section{The Cinema of Disgust and Subaltern Aspirations}

While not fully neo noir, the Tamil new wave did have a dominant theme, that of the marginalized which we can understand better through three prominent films - Aranya Kandam, Onanum Attinkuttiyum, Paruthiveeran. The first is a noir styled North Chennai gangster film, the second a flawed assassin in search of redemption in the yellow lights of a Chennai night and the third, a Madurai genre mix of caste and stigmatized criminals. Paruthiveeran (Warrior of Paruthiyur, 2007, Dir: Bala) portrays the love affair between Muthazhagu, the daughter of the village chief - a dominant caste patriarch (Thevar caste) - and her cousin, a dysfunctional and reckless marginal of mixed birth(Thevar-nomad). The opening scenes establish a festival milieu marked by a prominent religious symbol: the temple and its immediate external which is signified by activities like gambling, folk performances, drinking, fights and violence. Outside the temple, amongst the villagers, a battery of policemen control, inspect and verify the crowd for weapons.

There is a 'museumization' packaging of 'exotic' culture in an 'exterior' space constructing Madurai as a spectacle space(Dickens, 2015) in which both the 'sacred' and the 'profane' live together with institutional control and violence. The village is not a pastoral paradise but a den of caste/clan hate, bigotry and indolence in which the women characters are outliers either disgusted with their men or fighting for their aspirations against a caste ridden patriarchy. Muthazhagu expresses her love strongly and is not portrayed as submissive even so much as wolfishly devouring food to ensure strength before the beatings in a stubbornness that is tragiccomic.

In Aranya Kaandam (The Jungle Chapter ${ }^{\text {xxiii }}$, 2011 Dir: Kumaraja) visualizes a Chennai zone that is hiding in plain sight in tea shops and roadside stalls, till the characters start talking. Singaperumal the neurotic crime lord, is busy trying to eliminate his over ambitious enforcer Pasupathy, while his young mistress Subbu is having an illicit affair with his servant boy Sappae. The film does have neo-noir tones for its moral ambiguity, dim lighting, gratuitous violence, expository dialogue and a Tarantino style narrative with guerrilla cinematography backed by stylized fight sequences. There are also quick turns from comic interludes to tense showdowns, and most of the characters are casually immoral, rootless, ruthless and actually as plausible as real criminals and side-kicks with animal names - Singaperumal(Lion), Gajendran and Gajapathy(elephants), Sappae(dog) etc.

A medical student's act of saving a roadside man with gunshot wounds in Onaayum Aattukkuttiyum (The Wolf and The Lamb, Dir. Mysskin, 2013) comes to haunt him and his family in film that looks 'unstaged' among the killing spree through the long night which is yellow spot 
soaked with mercury vapour street lamps. The middle class medical student, driven by the green enthusiasm and idealism of a Doctor in making, manages to save the dying man before getting hurtled on a roller coaster of the Chennai night for his good deed. It is a different night though and not glamorous in a noir style way and what crawls out are the dregs of city life, the marginals no one sees or ignores - transgenders, flower sellers, blind people, destitutes, sick old people huddled in dirty blankets, homeless beggars on temple footpaths, all characters who live in the night and often anonymous for the urban dweller.

The 'cinema of disgust' is not about auteur aesthetics but violent and cruel reality which is after all the real world of the subaltern marginal. Films on OTP formats, not subjected to on land censorship laws, and series like Game of Thrones are known to have started a trend of extreme violent content. Film audiences are drawn to violence because they anticipate benefits, such as thrill and suspense and the promise to satisfy truth-seeking motivations. It can also be perceived as meaningful, moving and thought-provoking as well as admiration for acts of courage and moral beauty in the face of violence, or self-reflection with regard to violent impulses(Anne Bartsch \& Louise Mares, 2013) ${ }^{\mathrm{xxiv}}$. But for the new wave Tamil films the subaltern was not only class but caste too(Antonio Gramsci's concept of the subaltern encompasses an intersectionality of race, class, gender and religion) especially the 'otherness' that is strengthened by both the social and the political(Gramsci, 1971).

Is such intersectionality of caste and religion social transformative? Douglas(Paruthiveeran) stands out as a tragic-comedy relief and a silent cry for reason recognisable through his relentless aspiration for economic mobility despite being bullied at every stage of his enterprising journey. Casually persecuted, he works at the festival, at a tea shop, wants to invest in cattle, joins a folk troupe, sells candy and loses his job or business at every instance to the perceived comic relief of the audience. Unlike other inhabitants he is aspirational due to his larger 'social space' because as a converted Christian he is 'casteless' and his identify is the social transformation into 'otherness' outside the caste universe ${ }^{\mathrm{xxv}}$ and socio cultural ${ }^{\mathrm{xxvi}}$." His identity-less state though is a source of amusement for the main protagonists who constantly leads him to disaster through their comic-tragic bullying. Douglas though resists aggressive suppression amidst caste driven desolation and attempts to parley a decent livelihood as compared to the heroes who are both victims of bigotry and purveyors of violence against those they can in turn. Such comedy tracks in Tamil cinema have often represented a subaltern perspective with popular comedian Goundamani donning low caste characters - from graveyard worker to a barber to a washerman. His character, a barber, in Rakkayi Koyil, when served tea in a coconut shell at an upper caste chieftain's house says, "You are drinking from a silver tumbler". At least, you could have served us in a plastic cup. For how long, will we drink out of a coconut shell,"(K Ezhilarasan, 2019)

Pasupathy in Aranya Kaandam is an unlikely film gangster definitely not in the mould of a cinematic character with dysfunctional shades rather he sees a career roadblock. With a normal lower middle class life and a wife you are likely to stumble haggling with vegetable vendors in the dusty lanes of North Madras, he sees the crime world as a simple job opportunity, the only problem is he joined the wrong office. He wants to 'settle', a word typically used by middle class IT engineers hoping to get a good job with an Indian Technology, basically means you can have a comfortable life with family and kids. Having realized that he had made a poor career decision to hang around with a semi-retired gangster boss he is willing to antagonize him in the presence of the gang for a chance to make a big deal and 'settle'. In other narratives, Kodukkapulli, the young boy whose caring but careless father has lost his inheritance, and now he is looking for an 
opportunity to 'settle'. So is Subbu, the hapless mistress, not the archetypal noir femme fatale, but with enough chutzpah to manipulate her lover into killing her tormentor. Once free of tyranny, instead of hanging around to take revenge on the gang for the injustice meted to her, she saunters out with a suitcase full of cash to 'settle'.

In Onnayum Attukuttiyum, the choice for Chandru is very similar to that faced by thousands of poor, low caste medical students who cannot buy themselves a seat in the gated community of private medical universities. First generation aspirants from the underprivileged, they are trained by profession and value systems to save lives, help the sick and wounded and as a reward for their altruistic choice of not taking the easy way of an IT career they face daily unpredictable violence in the workplace(Radhakrishnan, $\mathrm{R}, 2015)$. Wanting to be a doctor is a nightmare of caste driven assessments, delayed scholarships, high-cost tuition fee, student debt, poor infrastructure and hygiene, violent and unforgiving patients, poor pay, dangerous and dirty work conditions and prospects that are at best remote. Every institution - the college, the government, the police, insurance companies and the bureaucracy - all take their pound of flesh so much so that wanting to be a Doctor is a deeply selfless and masochistic act (Neeraj Nagpal, 2017). Ironically, the establishment marginalizes ${ }^{\text {xxvii }}$ the medical students and extracts a cruel price for those who have the passion to serve society. In exchange for saving a dying man on the road, Chandru is hunted down by strange forces in the night before he turns from being the "haunted medical student' to one of the marginalized, moved by the actions of a selfless transgender and a tragic graveyard monologue. In a bloody Hippocrates role reversal he picks up the gun to save the last of the hunted.

The rise of the 'invisibles'(Rosalind Morris, 2010) as mainstream characters is clearly an important development in the new wave Tamil film and also that they are speaking to mass audiences. The otherness of the brutal and disgusting lives of the marginalized is far removed from the delicate refinement of the aesthete and when they 'talk in mainstream' it is a paradigm change in the narrative of cinema (Gayatri Spivak ${ }^{\text {xxviii }}$..if the subaltern can speak then, thank God, the subaltern is not a subaltern any more).

The mainstreaming of lower caste characters as marginalized protagonists is a milestone in Tamil films with Rajinikanth stepping in with his Dalit subtext film "Kalaa"(The Black One, released in Hindi in 2019). In a reprise of the epic Ramayana, the violence tinged 'Rajini persona' turns into an expository 'low caste persona' and his character, through curled lips, speaks to his spotless white clad antagonist '...you think because we are black we are dirty...". The film, in Hindi, is a juxtaposition of the Tamil identity of blackness and the valorous subjugated Tamil hero represented by the epic's noble villain Ravana pitted against the entitled, fair-skinned Northerner Ram. The sub-nationalism of the Dravidian movement based on ethnocentrism and language takes a low caste avatar and Tamil films will never be the same again. In fact, the homage to the subaltern couldn't have been better with the mainstreaming of the 'RajiniSubaltern' shockingly emerging from the Rajini persona that too in a superhit, 'mass scene' movie played by the biggest anti-hero turned establishment super hero of them all - Superstar Rajinikanth. 


\section{Notes}

\footnotetext{
${ }^{\text {i }}$ Parasakti (Goddess, 1952) film reiterated the splendor of Dravidian heritage and thematically depicted the triumph of rationalism over religiosity and priesthood.

${ }^{\text {ii }}$ Kumuthan Maderya invokes Fredrick G. Bailey to see, in the dark Rajini-persona's stylized irreverence, 'a supreme trick of identification' where the hero is not only identified as an ideal but simultaneously as one of them.

iii In Dalapathi, Rajnikanth playing the contemporary role of tragic hero Karna answers on why his mother abandoned him with 'as a child I was black and ugly so she threw me in a dustbin'.
}

iv Rasigar Manram or Fan Clubs have the reputation of being 'sponsored' by the hero through contributions, events and mania showcases to support full shows in the opening week of a film through gift schemes - Vishal Menon, April 14, 2016, The Hindu

${ }^{\vee}$ What's the secret behind 63-year-old superstar Rajinikanth's youthful looks? Kamini Mathai, TNN, Economic Times, Updated: Dec 08, 2014, 11.53 AM IST

${ }^{\mathrm{vi}}$ Below the Poverty Line, a term used to describe 400 million people who are different from another 300 million who are not below the line rather they are just 'poor, C. Rangarajan Committee Report, 30/o6/2014, Planning Commission, Govt. of India

${ }^{\text {vii }}$ Sethu starts as a college romance( popular genre in Indian films) and ends in a mental asylum, acquiring a cult status as a film that is grounded in realism.

viii Nandhu Sundaram, April 13, 2017 - 12:59, https://www.thenewsminute.com/article

${ }^{i x}$ K. Hariharan, Professor of Film at Ashoka University and National Award Winner for Best Film in 'The Open Magazine, Dark Comedy, After the Cinema of Disgust', http://www.openthemagazine.com/article/art-culture/after-thecinema-of-disgust

${ }^{x}$ Why Tamil cinema still battles financing woes, Updated: 08 Dec 2017, 05:54 AM IST, Lata Jha, The Mint

xi Times of India, Jan 14 ${ }^{\text {th }}$, 2017, 'I breathe because of Tamil Cinema, Anurag Kashyap', https://timesofindia. indiatimes.com /entertainment/tamil/movies/news/articleshow, Updated: Jan 14, 2017, $23: 29$ IST

xii The opening credits of Gangs of Wasseypur pay homage to the Madurai Triumvirate of Bala, Ameer and Sasikumar.

xiii Kumuthan Maderya, Arts Faculty, Anglo-Chinese Junior College \& National University of Singapore.

${ }^{\text {xiv }}$ Spectacle spaces: Production of caste in recent Tamil films, Dickens Leonard, Centre for Comparative Literature, University of Hyderabad, (C) 2015 Taylor \& Francis South Asian Popular Culture, 2015, Vol. 13, No. 2, 155-173, http://dx.doi.org/10.108o/14746689.2015.1088499

${ }^{x v}$ Andha Naal may have been adapted from the 1950 The Woman in Question directed by Anthony Asquith.

xvi Balachander's Wikipedia page has no reference to his Film Noir contributions instead he was more famous as a Musician, Singer and Concert genius.

xvii Claudia Adrien, 2014, 'Dashiell Hammett, Father of the Hard-Boiled Detective Novel', blog.bookstellyouwhy.com

xviii Some major novelists in films: Dashiell Hammett (The Maltese Falcon; 1941); Raymond Chandler (The Big Sleep, The Lady in the Lake, 1947); James M. Cain (The Postman Always Rings Twice), Double Indemnity (Chandler co-wrote the screenplay with Billy Wilder)) and Cornell Woolrich (The Bride Wore Black).

${ }^{x i x}$ Garry Leonard, Did Film Noir Really Happen, or Was It a Set-up? Articles 6 | film international issue 67 Articles Did Film Noir Really Happen, or Was It a Set-up? www.filmint.nu

${ }^{x x}$ Corey K.Creekmur, Themes and influences, Indian Film Noir, DOI:10.3366/edinburgh

${ }^{x x i}$ Homer B Pettey \& R.Barton Palmer, International Noir, Print publication date: 2014, Print ISBN-13: 9780748691104 Published to Edinburgh Scholarship Online: May 2015 DOI:

xxii Films by Guru Dutt, Goldie Anand and Raj Kapoor had noir style elements and songs too!

xxiii The Aranya Kandam a chapters in the epic Ramayana chronicles the hero Rama's encounters in the forest 


\footnotetext{
${ }^{\text {xxiv }}$ What attracts people to violent movies? March 28, 2013, ScienceDaily, Anne Bartsch, University of Augsburg, Germany and Louise Mares, University of Wisconsin-Madison, 63rd Annual Conference of the International Communication Association.

${ }^{x x v}$ Robinson, R. (2003). Religious conversion in India: Modes, motivations, and meanings (pp. 291-317). New Delhi: Oxford University Press.

${ }^{x x v i}$ Rambo, L. R. (1993). Understanding religious conversion. New Haven: Yale Univ Press

xxvii Shrivastava, Amit, 2017, The DailyO, Why, despite being a doctor in India, I advised my friend not to return home to practise, 10-12-2017 and Why doctors like me in India are against National Medical Commission Bill, 2017, https://www.dailyo.in/politics

xxviii Gayatri Chakravorty Spivak's "Can the Subaltern Speak?" transformed the analysis of colonialism through an eloquent argument on the historical and ideological factors that obstruct the possibility of being heard for those who inhabit the periphery and her work has been widely cited, invoked, imitated, and critiqued.
}

\section{References}

Claudia A. (2014). Dashiell Hammett the father of the hard boiled, American Literature https://blog.bookstellyouwhy.com/dashiell-hammett-father-of-the-hard-boiled-detective-novel

Dickens, L. (2015). Spectacle spaces: Production of caste in recent Tamil films, Centre for Comparative Literature, University of Hyderabad, Hyderabad, India, Taylor \& Francis South Asian Popular Culture, 2015 Vol. 13, No. 2, 155-173,

Ezhilarasan, K. (2019). Caste in Tamil Cinema, Express News Service Published: 2oth October 2019 http://www.newindianexpress.com/entertainment/tamil/2019/oct/20/caste-in-tamil-cinema-astory-in-four-acts-2050211.html

Spivak, G.C. (2010). Can the Subaltern Speak? Republished in Rosalind Morris (ed.). Reflections on the History of an Idea (New York: Columbia University Press, 2010). pp. 21-80

Gramsci, A. (1971). Selections from the Prison Notebooks. International Publishers. ISBN o-7178-0397-X.

Guha, R. (2015). Subaltern Studies I: Writings on South Asian History and Society (New Delhi: Oxford University Press, 1982), p.8. Ed. Debjani Ganguly, 'Subaltern Studies 30 Years On', South Asia, March 2015.

Hariharan, K. (2013). After the Cinema of Disgust, Film Studies and Broadcast Journalism, Ashoka University, The Open Magazine, Dark Comedy, http://www.openthemagazine.com/article/artculture/after-the-cinema-of-disgust

Krishnan, R. (2008). Imaginary Geographies: The Makings of 'South' in Contemporary Tamil Cinema. Tamil Cinema: The Cultural Politics of India's Other Film Industry. Ed. Selvaraj Velayutham. Oxon: Routledge, 139-53. Print.

Krishnan, R. (2010). "Kathanayaganin Maranam." ("Death of the Hero"), Katchipizhai Vol. 1 (August/September 2010): 7-11.

Maderya, K. (2010). Rage against the State: Historicizing the 'Angry Young Man' in Tamil Cinema. Jump Cut 52, Print. (http://ejumpcut.org/archive/jc52.2010)

Maderya, K. (2013). Red Flags in Tamil cinema agitprop and art-house during the Cold War. kumuthan_martheya@acjc.edu.sg, Historical Journal of Film, Radio \& Television. Mar2o16, Vol. 36 Issue 1, p68-87. 2op.

Marcus, E. G. (2011). Rethinking the subaltern and the question of censorship in Gramsci's Prison Notebooks, Postcolonial Studies, 14:4, 387-404, DOI: 10.1080/13688790.2011.641913 
Marie-Hélène Zérah. (2017). Understanding Subaltern Urbanisation in India and its Impact, A series of Interpretations drawing on a new book on small towns-Urban Governance, 2017, http://www.cprindia.org/people

Morris, R. (2010). Can the Subaltern Speak? Reflections on the History of an Idea, Columbia University Press, PUB DATE: March 2010, ISBN: 9780231143844

Niranjana, T. (1994). Whose Nation? Tourists and Terrorists in Roja. Economic and Political Weekly 24.3 (January 1994): 79-82. Print.

Nagpal, N. (2017), Incidents of violence against doctors in India, National Medical Journal of India, Medicine and Society, Volume: 30, Issue : 2, Page : 97-100

Pandian, M.S.S. (1995). Beyond Colonial Crumbs. Cambridge School, Identity Politics and Dravidian Movement(s), Economic and Political Weekly, Vol. 30, No. 7/8 (Feb. 18-25, 1995), pp. 385-391 https://www.jstor.org/stable/4402414

Pillai, S. E. (2015). Madras Studios: Narrative, Genre, and Ideology in Tamil Cinema. SAGE Publications. ISBN 978-93-5150-212-8.

Radhakrishnan, R. (2015). Why I will never allow my child to become a doctor in India, Quartz India, https://qz.com/india/406682/why-i-will-never-allow-my-child-to-become-a-doctor-in-india/

\section{Author Profile:}

Dr. Sreeram Gopalkrishnan has a PhD in Mass Communications, MS in Communications, MBA from NMIMS and has attended Executive Programmes at the IndianOil Institute of Petroleum Management and Mudra Institute of Communications \& Advertising(MICA). He has a UGC NET Lectureship qualification and published research papers in leading peer-reviewed and Scopus Indexed Management and Communications Research Journals. Dr Sreeram started his career in the IT Industry before getting into the media industry as a Scriptwriter and Copywriter in companies like OS Studios \& RK Swamy BBDO. He joined Fortune 500 company IndianOil as a Probationary Officer and worked in senior leadership positions pan India before shifting to academics. In 2016, he received the prestigious Best MBA Faculty award from the premier Bombay Management Association. In 2017, he joined Symbiosis International University as Associate Professor and took over as Director, Symbiosis Centre for Media and Communications. His research interests are in Lobbying Studies, CRM, Branding, Film Studies and Marketing Analytics and has contributed two books - Petroleum Perspectives and the Future - published by the D.Y.Patil Foundation, Pune \& Cloud Computing: The Surge before the Storm by Cambridge Publishing, U.K. 